\title{
ARTICLES
}

Anne Schneider*

\section{Res Judicata in Criminal Matters and the European Courts - A Comparison Between Germany and Italy (Part I)}

\section{The possible impact of judgements by the European Courts on national res judicata}

National criminal law is to a large extent influenced by European Law and especially by decisions of the European Courts. European Courts are the Court of Justice of the European Union (Art. 251 et seq. TFEU, in the following "ECJ") and the European Court of Human Rights (in the following "ECtHR"). ${ }^{1}$ The myriad ways in which EU Law and the European Convention on Human Rights (in the following "ECHR") have an impact on criminal law and criminal procedure have already been explained elsewhere and do not need to be discussed in general..$^{2}$ However, European jurisprudence can also provide a challenge to the national principle of res judicata. Final judgements, i.e. those that cannot be challenged on appeal, are endowed with res judicata. Res judicata is a fundamental principle of the European legal systems, which provides legal certainty. It is well established in every Member State and High Contracting Party under national constitutional law. ${ }^{3}$ But what happens if a final judgement is contrary to the ECHR or EU law?

This is the question that shall be discussed in this paper by comparing the German and Italian solutions. In order to do so, it is first necessary to establish in which situations a potential conflict can arise between the judgements of the European Courts and res judicata.

* Dr. Anne Schneider LL.M. (U.W.E.) is Research Associate at the Department of Criminal Law at the University of Bonn, Germany. This essay was written during a research stay at the Università di Torino in Italy. The author wishes to thank Prof. Serena Quattrocolo of the above mentioned university for her hospitality. Part 2 of the essay will be published in EuCLR 2/2016.

1 The General Court of the European Union (Art. 259 TFEU) will not be considered separately in this paper.

2 See e.g. B. Hecker, Europäisches Strafrecht, $5^{\text {th }}$ edition, 2015, passim.

3 Protocol No. 7 to the Convention, which contains rules on res judicata and the reopening of trials, has not been ratified by all High Contracting Parties.

DOI: $10.5771 / 2193-5505-2016-1-7$ 


\section{ECtHR jurisprudence}

The first situation is that the European Court of Human Rights (ECtHR) has rendered a judgement on the exact matter that was part of the national decision having res judicata. This is typical for decisions of the ECtHR because their majority deals with individual applications against national decisions of the Contracting Parties (Art.34 ECHR). As an individual application is only admissible after all domestic remedies have been exhausted (Art. 35 para. 1 ECHR), the decisions that have allegedly violated the ECHR are naturally final in the sense of having res judicata.

The second situation is that the ECtHR has ruled on a matter that is of fundamental importance for a large number of cases. If some of these cases have already been finally disposed of by the Contracting Parties prior to the decision of the Court, the question arises as to whether the new interpretation of the Human Rights Convention introduced by ECtHR must not only be applied to new cases, but also retrospectively to those cases that have already been finally adjudicated. An example for this kind of problem is the ECtHR decision in the Grande Stevens v. Italy case. ${ }^{4}$ Here, the court held that the conviction of Mr. Grande Stevens by the criminal courts after having already received a penalty from the Italian Securities and Exchange Commission (CON$\mathrm{SOB}$ ) for the same facts was in breach of the ne bis in idem principle (Art. 4 of Protocol No. 7). ${ }^{5}$ Notwithstanding the implications of the decision for Grande Stevens, ${ }^{6}$ it is clear from the facts that the decision affects a practice that has been well established in Italy (and other Contracting Parties). In the past, there have undoubtedly been several convictions by criminal courts after a final decision by CONSOB. The question is now what should happen to all those final convictions that are also in breach of the ne bis in idem principle, but have not been challenged in front of the ECtHR.

This question is also especially important because the ECtHR has developed the strategy to select one case among many that concern the same problem and then adjourn the other cases (so called pilot-judgement procedure, rule 61 of the Rules of Court). ${ }^{7}$ Although the ECtHR can re-examine the adjourned applications (rule 61 para. 8), the system is based on the expectation that the Contracting Parties will take note of the decision.

4 European Court of Human Rights (ECtHR), Grande Stevens v. Italy, Application no. 18640/10, Judgement 3 April 2014. See also the overview in M. Gargantini, Public Enforcement of Market Abuse bans. The ECtHR Grande Stevens Decision, Journal of Financial Regulation 2015, p. 1 et seq.

5 ECtHR, Grande Stevens v. Italy (fn. 4 ), margin no 228.

6 At the time of the judgement by the ECtHR, the criminal proceedings had not yet been finally adjudicated so that there was no res judicata problem, see ECtHR, Grande Stevens v. Italy (fn. 4), margin no 52.

7 See M. Breuer, Zur Fortentwicklungen (sic!) der Piloturteilstechnik durch den EGMR, Europäische Grundrechte-Zeitung (EuGRZ) 2012, p.1 et seq. (1 et seq.); S. Swoboda, Das Recht der Wiederaufnahme in Europa, Onlinezeitschrift für Höchstrichterliche Rechtsprechung zum Strafrecht (HRRS) 2009, p. 188 et seq. (192). 


\section{ECJ jurisprudence}

Similar problems arise with ECJ jurisprudence. However, the number of cases that directly affect criminal final judgements is significantly lower. This is because ECJ decisions are mostly the result of a reference for preliminary ruling (Art. 267 TFEU). ${ }^{8}$ Accordingly, the procedure before the national court is still pending when the ECJ decides, so that there is no national judgement that has acquired res judicata.

The other procedures before the ECJ, such as the infringement procedure (Art. 258 TFEU), do not typically concern single cases that have given rise to a criminal decision with res judicata, but rather a practice that has been established in the Member State. However, under certain circumstances an individual can institute proceedings against legislative or other acts by the EU (Art. 263, 264 TFEU). This could theoretically lead to a judgement by the ECJ declaring void EU law that forms the basis of national criminal proceedings (Art. 263 para. 4 var. 2 TFEU). In practice, the requirements for admitting such a complaint by an individual are so high that they will rarely be met in criminal cases, especially as the EU does not take direct action in criminal matters. Moreover, such an action for annulment must be filed within two months after the publication of the measure or the notification of the plaintiff (Art. 263 para. 6 TFEU). Even if the ECJ takes a long time to decide the matter, it is not likely that a decision is taken only after the whole process of judicial review in the Member States national system has been exhausted and the national judgement has become res judicata. ${ }^{9} \mathrm{~A}$ binding decision by the ECJ in the exact case that has been finally judged in the Member State is also possible if the defendant has claimed compensation, e.g. for refusal to refer the matter for preliminary ruling to the ECJ. ${ }^{10}$ However, such a decision does not concern the same subject matter, e.g. a criminal conviction, but falls within the area of state liability.

Far more likely than a judgement on the exact matter that is the basis of the criminal proceedings in the Member State is the second situation: the ECJ decides on a criminal matter, e.g. in a preliminary ruling, that is of importance for other cases. This scenario has occurred often and will probably occur in the future. An example: in German law, driving without a licence is a criminal offence $\left(\mathbb{2} 21 \mathrm{StVG}^{11}\right)$. The recognition of driver's licences that have been issued in other Member States is governed by Directive

8 In 2011, more than $60 \%$ of new cases were references for a preliminary ruling. Considering that $25 \%$ of cases were appeals, this effectively means that $80 \%$ of newly initiated proceedings are references for preliminary ruling. See the Court's statistics, available at http://curia.e uropa.eu/jcms/upload/docs/application/pdf/2012-06/ra2011_statistiques_cour_en.pdf (last access on 24 October 2015).

9 Probably, the Member State will stay criminal proceedings anyway if the outcome is dependent on a decision by the European Courts, see, e.g. $\$ 262$ para. 2 StPO (German Code of Criminal Procedure).

10 European Court of Justice (ECJ) 19.11.1991, cases C-6/90 and C-9/90 (Francovich and others), [1991] ECR I-5403, margin no 33 et seq.; European Court of Justice (ECJ) 30.9.2003, case C-221/01 (Köbler), [2003] ECR I-10239, margin no 30 et seq.

11 "Straßenverkehrsgesetz" = Road Traffic Law.

EuCLR Vol. 6, 1/2016 
2006/126/EC. ${ }^{12}$ The interpretation of this Directive has given rise to numerous preliminary rulings by the ECtHR which concern criminal liability under $\$ 21 \mathrm{StVG} \cdot{ }^{13}$ These rulings had influence on not only the case in question, but any conviction of foreigners on the basis of this law. Thus the question was whether all these people that had been wrongfully convicted could achieve a reopening of their case.

\section{The relationship between national res judicata and the ECHR and EU law}

Before analysing the German and Italian legal systems, it is useful to have a look at the sources which cause the problem of a potential challenge to res judicata, namely the ECHR and EU law. What do these legal systems say on the crucial question of what happens in case of a conflict between those legal orders and national judgements endowed with res judicata? Is there an obligation to revoke judgements with res judicata in case of a violation of the ECHR or EU law? These questions will be discussed in this chapter.

\section{ECHR}

The ECHR contains regulations on the effects of judgements of the ECtHR. According to Art. 46 ECHR, the High Contracting Parties are obliged to abide by a final judgement to which they are parties. This obligation is necessary because judgements by the ECtHR do not have executive force. The ECHR is an international convention and as such part of international law. Its rank in the hierarchy of law thus depends on the importance that the ECHR has been granted in the national systems of the Contracting Parties.

However, the question is to what extent the Contracting Parties must abide by the decisions of the ECtHR to which they are party. Art. 41 ECHR enables the Court to grant just satisfaction "if the internal law of the High Contracting Party concerned allows only partial reparation". This condition shows that restitutio in integrum, full reparation, is the desired objective and just satisfaction the substitute. However, generally, it is up to the Contracting Parties to decide in which way they want to implement a decision by the ECtHR, as long as they do indeed address the problem for the future. ${ }^{14}$ By enabling the Court to grant just satisfaction, Art. 41 ECHR clearly shows that full reparation, albeit desirable, is not required by the Contracting Party. Following this line of argument, the ECtHR has repeatedly stated explicitly that the ECHR

12 Directive 2006/126/EC of the European Parliament and of the Council of 20 December 2006 on driving licences (Recast), OJ 2006 L 403/18.

13 For example, European Court of Justice (ECJ) 26.4.2012, case C-419/10 (Hofmann).

14 European Court of Human Rights (Grand Chamber) [ECtHR (GC)], Verein gegen Tierfabriken v. Switzerland No. 2, Application no. 32772/02, Judgement 30 June 2009, margin no 88 . 
does not require the Contracting Parties to go back on judgements with res judicata if national law does not provide this possibility. ${ }^{15}$

Nonetheless, in the last couple of years, the jurisprudence of the ECtHR has evolved. When analysing the more recent judgements, it becomes clear that the ECtHR has taken to suggesting much more specific remedies than before. ${ }^{16}$ In case of systematic and structural deficiencies on the part of the Contracting Parties, the ECtHR can make use of the pilot-judgement procedure and take one case to exemplify general measures that the Contracting Party should adopt in order to end the violation of human rights. ${ }^{17}$ By these means, the Court hopes to reduce its backlog of cases. ${ }^{18}$ However, even in cases that refer to a singular problem, the Court has started making explicit suggestions on the best method of reparation, sometimes even as part of the operative part of the judgement. ${ }^{19}$ As the operative part of the judgement is binding (Art. 46 ECHR), the Contracting Parties can thus be obliged to implement a specific measure. Nonetheless, the legal basis for the order of specific measures is somehow shaky because Art. 46 ECHR does not empower the Court to give precise orders on the execution of its judgements. ${ }^{20}$ On the contrary, the execution of judgements is supervised by the Committee of Ministers. On the other hand, the Committee of Ministers is bound by the judgement of the Court (Art. 46 para. 3 ECHR). In the event of non-compliance with a judgement, the Committee refers the matter to the Court. Moreover, if the Committee is satisfied with the execution, but the individual concerned is not, he or she can again file a complaint before the ECtHR for violation of human rights by non-execution. ${ }^{21}$

This change in the ECtHR jurisprudence has also had an effect on the Court's view on res judicata. The traditional view that the Contracting Parties are not obliged to reopen proceedings has changed. In 2000, the Committee of Ministers suggested in its Recommendation No. R (2000) 2 the adoption of reopening procedures by the Contracting Parties.22 The reason was that "in exceptional circumstances the re-examination of a case or a reopening of proceedings has proved the most efficient, if not the

15 See only ECtHR (GC), Verein gegen Tierfabriken v. Switzerland No. 2 (fn. 14), margin no $89,90$.

16 See the overview in J. Jahn, Ruling (In)directly through Individual Measures? Effect and Legitimacy of the ECtHR's New Remedial Power, Zeitschrift für ausländisches öffentliches Recht und Völkerrecht (ZaöRV) 2014, p. 1 et seq. (4 et seq.).

17 The first decision of this kind was European Court of Human Rights (ECtHR), Broniowski v. Poland, Application no. 31443/96, Judgement 22 June 2004.

18 Jahn, ZaöRV 2014, p. 1 et seq. (2-3).

19 See, e.g., European Court of Human Rights (ECtHR), Volkov v. Ukraine, Application no. 21722/11, Judgement 9 January 2013, operative provision 9: "Ukraine shall secure the applicant's reinstatement to the post of judge of the Supreme Court at the earliest possible date".

20 See also Jahn, ZaöRV 2014, p. 1 et seq. (10).

21 ECtHR (GC), Verein gegen Tierfabriken v. Switzerland No. 2 (fn. 14 ).

22 Most of the Contracting Parties seem to have heeded the advice, see the recent survey by the Committee of experts on the Reform of the Court, DH-GDR(2015)002.

EuCLR Vol. 6, 1/2016 
only, means of achieving restitutio in integrum" 23 . In particular, cases in which the national judgement has led to very negative consequences that cannot be compensated by money fall within the ambit of this rule if either the national judgement is profoundly against the Convention or the violation was based on grave procedural errors. ${ }^{24} \mathrm{Ac}-$ cording to the Committee of Ministers, this is especially the case in criminal proceedings. ${ }^{25}$

The Court followed this assessment when it, for the first time, included allowing a reopening of criminal proceedings in the operative part of the judgement in Sejdovic v. Italy. ${ }^{26}$ This case concerned an Italian trial in absentia and the application of Art. 175 of the Italian Code of Criminal Procedure ("Codice di Procedura Penale", in the following "C.p.p."). ${ }^{27}$ The Court considered the Italian legislation to violate Art. 6 ECHR and held that the law, as a general measure, should be changed in order to allow the re-examination of these trials. ${ }^{28}$ However, this judgement was later changed by the Grand Chamber to a mere recommendation to allow, in the generality of cases, a reexamination. ${ }^{29}$ Therefore, Sejdovic v. Italy is not an example of a binding order of the reopening of a criminal trial. A valid and legally binding operative provision ordering the reopening of criminal proceedings can, however, be found in the Court's judgement Lungoci c. Roumanie. ${ }^{30}$ In this case, the applicant had been denied access to a tribunal established by the law in a civil matter, which is a violation of Art. 6 para. 1 ECHR. The Court explicitly referred to the Romanian reopening procedure that allows for reopening in the aftermath of ECtHR decisions and ordered Romania to assure such a reopening within six months. ${ }^{31}$ A similar specific measure was ordered in

23 Committee of Ministers, Recommendation No. R (2000) 2.

24 Committee of Ministers, Recommendation No. R (2000) 2 II.

25 Explanatory Memorandum to Recommendation No. R (2000) 2, margin no 10.

26 European Court of Human Rights (ECtHR), Sejdovic v. Italy, Application no. 56581/00, Judgement 10 November 2004, operative provisions 2 and 3.

27 Art. 175 para. 2 C.p.p. used to provide for a remedy against in absentia judgements, whenever the defendant or the convicted could demonstrate that they were not aware of the proceeding (and of the conviction) against them.

28 This decision did not come as a surprise. Italian trials in absentia had been deemed a violation of Art. 6 ECHR before, see, e.g., European Court of Human Rights (ECtHR), F.C.B. v. Italy, Application no. 12151/86, Judgement 28 August 1991.

29 European Court of Human Rights (Grand Chamber) [ECtHR (GC)], Sejdovic v. Italy, Application no. 56581/00, Judgement 1 March 2006, margin no 108 et seq. The reason for not ordering a general measure was that Italy had already enacted new legislation after the events in Sejdovic v. Italy (in particular, Law of $22^{\text {nd }}$ April 2005, no. 60). The Court wanted to see how the new legislation worked before finding a systematic failure, $E C t H R(G C)$, Sejdovic v. Italy (ibid.), margin no 123 et seq; European Court of Human Rights (ECtHR), R.R. c. Italie, Application no. 42191, Judgement 9 June 2005, margin no 68.

30 European Courts of Human Rights (ECtHR), Lungoci c. Roumanie, Application no. 62710/00, Judgement 26 January 2006, operative provision 3 a): “l'Etat défendeur assure, dans les six mois à compter du jour où l'arrêt sera devenu définitif, conformément à l'article $44 \$ 2$ de la Convention, et si la requérante le désire, la réouverture de la procedure [...]”.

31 ECtHR, Lungoci c. Roumanie (fn. 30), margin no 56. 
the operative part of the judgement in Ajdaric v. Croatia. ${ }^{32}$ In this case, the applicant had been convicted for murder on the basis of hearsay evidence by a witness with psychiatric problems. The ECtHR found that the national courts had not properly addressed the inconsistencies in the witness' statement, thus violating Art. 6 ECHR. It stated that "the most appropriate form of redress would be the retrial of the applicant" ${ }^{33}$. In contrast to Lungoci v. Roumanie, the ECtHR did not refer to Croatian law and the possibilities it provides for reopening procedures. This indicates that the Court might consider a retrial necessary even if national law did not provide this possibility. Nonetheless, as Croatian law does indeed have a reopening procedure in criminal law and explicitly provides for reopening in the case of an ECtHR decision (Art. 430 Croatian Criminal Procedure Act), it was easy for the Court to give this order. ${ }^{34}$

As the analysis has shown, the situation is still unresolved. The case law is rather ambiguous. On the one hand, the ECtHR has taken to suggesting specific measures and has even ordered the reopening of cases, but, so far, only in situations where the Contracting Party had provided such a possibility. On the other hand, the Court stated in another judgement with regard to the reopening of proceedings that it "clearly does not have jurisdiction to order such measures" 35 . A similar line seems to be adopted by the Parliamentary Assembly when it deplores that some Contracting Parties (Italy and Turkey) had not yet allowed the reopening of criminal proceedings in case of an ECtHR decision, nor taken other similar measures. ${ }^{36}$ Again, there is a strong suggestion to introduce such a measure, but it is also possible for the High Contracting Party to avert such a solution by providing different measures. Nonetheless, the development so far suggests that a specific measure that is part of the operative part of the judgement is considered as binding by the Court, the Contracting Party concerned and the Committee of Ministers because it is deemed to fall within the ambit of Art. 46 para. 1 ECHR. ${ }^{37}$ Accordingly, if the Court orders such a measure, the Contracting Party must comply with it, if necessary by a change of legislation. This has, so far,

32 European Court of Human Rights (ECtHR), Ajdaric v. Croatia, Application no. 20883/09, Judgement 13 December 2011, operative provision 4 a): "the respondent State shall secure, within six months of the date on which the judgement becomes final in accordance with Article $44 \rrbracket 2$ of the Convention, should the applicant so request, the reopening of the proceedings".

33 ECtHR, Ajdaric v. Croatia (fn. 32 ), margin no 58.

34 Art. 430 Croatian Criminal Procedure Act: "The provisions of this chapter on the reopening of criminal basis of a decision of the Constitutional Court of the Republic of Croatia which annulled or vacated the law on the basis of which the final decision was rendered, or on the basis of a decision of the European Court for Human Rights which refers to some ground for the reopening of criminal proceedings or for an extraordinary review of the final judgement." The unofficial translation is taken from http://www.vsrh.hr/CustomPages/Static/HR V/Files/Legislation_Criminal-Procedure-Act.pdf (last access on 24 October 2015).

35 ECtHR (GC), Verein gegen Tierfabriken v. Switzerland No. 2 (fn. 14 ), margin no 89.

36 Parliamentary Assembly, Resolution no. 1516 (2006) of 2.10.2006, point 11.1.

37 See also Brener, EuGRZ 2012, p. 1 et seq. (2); G. Sorrenti, Crisi e tenuta del mito del giudicato nell'impatto con le condanne emesse a Strasburgo, Rivista di Diritto Pubblico Italiano, Comparato, Europeo, No. 2/2015, p. 1 et seq. (2 et seq.), available at: http://www.federalismi .it/ (last access on 24 October 2015); F. Callari, La Revisione, $2^{\text {nd }}$ edition, 2012, pp. 265.

EuCLR Vol. 6, 1/2016 
mostly been the case when there had been a grave violation of Art. 6 ECHR, casting doubt on the overall fairness of proceedings. ${ }^{38}$ Indeed, in the case of, e.g., an unjustified trial in absentia, it is difficult to imagine that monetary compensation - which does normally not amount to much anyway - can constitute a sufficient remedy. ${ }^{39}$ In these situations, the reopening of criminal proceedings may well be the only way to achieve full satisfaction. The Committee of Ministers has, indeed, taken this point of view in its Final Resolution in Dorigo v. Italy when first encouraging, then strongly urging and finally calling for the adoption of legislation that allows the reopening of trial. ${ }^{40}$ To conclude, one can say that in certain circumstances Art. 46 ECHR may require the Contracting Parties involved to reopen criminal proceedings.

In the light of the difficulties of establishing an obligation to reopen proceedings that have been the subject of a judgement by the ECtHR, it must be concluded that the Contracting Parties are not obliged to go back on final judgements that do not affect them directly. This does not mean that judgements by the ECtHR do not have an erga omnes effect. ${ }^{41}$ Art. 1 ECHR obliges the High Contracting Parties to respect the $\mathrm{Hu}$ man Rights. The Human Rights are defined by the ECtHR. Accordingly, all judgements of the ECtHR must be taken into account by the Contracting Parties when interpreting national law in the light of Human Rights. ${ }^{42}$ Whether they must also be applied retroactively to cases that happened before the judgement of the ECtHR is a question that is discussed by Judge Pinto de Albuquerque in his Concurring Opinion to Fabris. ${ }^{43}$ The claimant in Fabris had been given a reduced share of his inheritance due to French law that at that time provided that children born in adultery were only entitled to half the share of the inheritance of other children. During the lengthy legal proceedings in France, the ECtHR decided in another judgement, Masurek v. France, that the French law was discrimination on the ground of birth and thus violated Art. 14 ECHR. ${ }^{44}$ France, accordingly, adopted new legislation. However, due to transitional rules, the new law did not apply to M. Fabris who, therefore, filed an application to the ECtHR. The question was whether Masurek v. France applied to facts that had occurred prior to the judgement. Judge Pinto de Albuquerque writes: "The retroactive effect of the Court's judgements calls into question the foreseeability of judicial activity. Hence, legal certainty favours the prospective effect of judgements. Nevertheless, the full implementation of the rights and freedoms protected by the Convention may

38 See, e.g., ECtHR, Sejdovic v. Italy (fn. 26 ).

39 Moreover, monetary compensation would mean that the ECtHR would need to speculate on the outcome of the trial without the violation of procedural law - something that it is not likely to do, M. Brener, Staatshaftung für judikatives Unrecht, 2011, p. 581.

40 Committee of Ministers, Final Resolution CM/ResDH(2007)83.

41 See, e.g., T. Masuch, Zur fallübergreifenden Bindungswirkung von Urteilen des EGMR, Neue Zeitschrift für Verwaltungsrecht (NVwZ) 2000, p. 1266 et seq. (1267 et seq.).

42 See the Concurring Opinion of Judge Pinto de Albuquerque to European Court of Human Rights (Grand Chamber) [ECtHR (GC)], Fabris v. France, Application no. 16574/08, Judgement 7 February 2013.

$43 \operatorname{ECtHR}(G C)$, Fabris v. France (fn. 42 ).

44 ECtHR, Mazurek v. France, 1.2.2000, Case 34406/97, $\$ 55$. 
require that a Court's judgement be applied retroactively, that is to say, to facts submitted in a new application which have occurred prior to the date when the judgement became final." 45 At first glance, this looks as if the judge supported a retroactive application. However, a closer look reveals that the judge does not promote to apply the rules of Masurek $v$. France to cases that have been the subject of a final decision prior to the judgement of the ECtHR, but only to those that are still pending. ${ }^{46}$ This implies that similar decisions with res judicata, despite being contrary to Art. 14 ECHR, do not have to be reconsidered in the wake of Masurek v. France.

An exception to this rule is the so-called pilot-judgement procedure. The pilotjudgement procedure has first been developed by case law. ${ }^{47}$ In 2011, it was introduced in the Rules of Court as rule $61 .{ }^{48}$ In case of a structural or systematic problem that has given rise to numerous applications, the ECtHR can adopt a pilot judgement (rule 61 para. 1). In the operative part of the pilot judgement, the Court proposes general measures that the Contracting Party is required to take in order to remedy the problem. It can also set a period of time for compliance with the pilot judgement (rule 61 para. 4). After rendering a pilot judgement, the Court may adjourn all similar applications, but may also continue examining them (rule 61 para. 6 lit. a, c). ${ }^{49}$

The idea behind this procedure is that the Contracting Party can provide a solution that makes the numerous other applications unnecessary. ${ }^{50}$ However, such a system only works if the Contracting Party takes care to address the systematic problem effectively. If the most effective, or even the only effective, method to do so is to reopen proceedings, the Contracting Party must thus make sure that this applies to all the pending applications. Accordingly, in this situation the Contracting Party needs to apply the pilot judgement even to those proceedings that were not adjudicated by the ECtHR. Although this obligation makes perfect sense in light of the aim of the pilotjudgement procedure to reduce the backlog of cases pending at the ECtHR, some doubts remain as to its legal basis. This is because the pilot-judgement procedure is not part of the Convention, but only regulated in the Rules of Court. ${ }^{51}$ Whether Art. 46 ECHR can really be interpreted to put such an obligation on the Contracting Parties, can well be doubted. Nonetheless, since its introduction in 2004, the pilot-judgement procedure has overall been accepted by the Contracting Parties, and they have indeed taken care to address systematic problems in the ways suggested by the ECtHR. Such

45 Concurring Opinion of Judge Pinto de Albuquerque to ECtHR (GC), Fabris v. France (fn. 42 ).

46 Concurring Opinion of Judge Pinto de Albuquerque to ECtHR (GC), Fabris v. France (fn. 42 ), fn. 21.

47 ECtHR, Broniowski v. Poland (fn. 17 ), operative provisions 3 and 4.

48 Initiatives to include the pilot-judgement procedure in the Convention have been unsuccessful, Brener, EuGRZ 2012, p. 1 et seq. (2).

49 The latter course was, for example, taken in the first pilot judgement against Germany, European Court of Human Rights (ECtHR), Rumpf v. Germany, Application no. 46344/06, Judgement 2 September 2010, margin no 75.

50 SeeECtHR, Broniowski v. Poland (fn. 17 ), margin no 193.

51 Brewer, EuGRZ 2012, p. 1 et seq. (2).

EuCLR Vol. 6, 1/2016 
a recognition of a newly developed procedure can be regarded as "subsequent practice in the application of the treaty which establishes the agreement of the parties regarding its interpretation" under Art. 31 para. 3 lit. b of the Vienna Convention on the law of treaties. ${ }^{52}$ As such, a practice of the Contracting Parties that has been developed after the Convention has been signed must be taken into account when interpreting the ECHR. Accordingly, Art. 46 ECHR can be interpreted as obliging the Contracting Parties to address systematic problems that have been pointed out in a pilot judgement.

\section{EU law}

The ECJ, who plays a prominent role in defining the relationship of EU law and national law, has rendered several judgements that concern the impact of EU law on res judicata. In its first direct ruling on this issue, Kapferer, the Court held that EU law does not oblige the Member States to go back on judgements endowed with res judicata, even if these judgements are contrary to EU law. ${ }^{53}$ This has been stressed ever since. ${ }^{54}$ This is because the obligation to provide sufficient legal remedies, which is guaranteed by Art. 19 para. 1 subpara. 2 TEU and Art. 47 CFR, does not include an obligation to go back on judgements with res judicata, at least not if the Member State has provided the possibility of an appeal. ${ }^{55}$

However, in the Lucchini decision, the ECJ held that the respective Member State, Italy, was indeed required to go back on a decision granting state aid to a person without legal foundation in Union law. ${ }^{56}$ Lucchini concerned a case where state aid had been granted by the national court although the Commission had already decided that this state aid was illegal with regard to EU law. As state aid from EU sources falls within the exclusive competence of the EU, the national court ought not to have taken such a decision. The ECJ thus held that a national court was "under a duty to give full effect to those provisions [of Community law], if necessary refusing of its own motion to apply any conflicting provision of national legislation" 57 . A judgement that totally disregards the EU's competence - in this case by granting illegal state aid - thus can be revoked despite having res judicata in order to ensure the effective application of EU law. Nonetheless, the situation of Lucchini was special because it referred to an area of law that falls within the exclusive competence of the EU or, more precisely for that

52 Brener, EuGRZ 2012, p. 1 et seq. (2).

53 European Court of Justice (ECJ) 16.3.2006, case C-234/04 (Kapferer), [20069 ECR I-2605, margin no 21.

54 Most recently in European Court of Justice (ECJ) 6.10.2015, case C-69/14 (Târșia), margin no 29; European Court of Justice (ECJ) 10.7.2014, case C 213/13 (Impresa Pizzarotti), margin no 59 with further references.

55 See Opinion of AG Jääskinen, 23.4.2015, case C-69/14 (Târșia), margin no 28 et seq.

56 European Court of Justice (ECJ) 18.7.2007, case C-119/05 (Lucchini), [2007] ECR I-6228, margin no 63.

57 ECJ, Lucchini (fn. 56) I-6228, margin no 61. 
time, the EC..$^{58}$ This is not the case with criminal law and criminal procedure. Accordingly, the Lucchini decision must be regarded as an exception to the principle laid out above that is not applicable in case of concurrent competences. ${ }^{59}$

Nonetheless, Lucchini points to two well-established principles that govern the Member States when applying EU law: the principles of equivalence and effectiveness. ${ }^{60}$ These principles follow from the principle of sincere cooperation that is inscribed in Art. 4 para. 3 TEU. The principle of equivalence means that EU law must be threatened as equivalent to national law. The principle of effectiveness means that the Member States must ensure that EU law has an effect. This was the basis of the Lucchini decision: in this case, EU law could only be effective if the national decision was set aside.

From these principles, it follows that legal remedies for failure to comply with EU law must exist and that they must be equal to those for failure to comply with national law. ${ }^{61}$ The same is true for judgements endowed with res judicata. Although Member States are not obliged to allow going back on judgements with res judicata, apart from the situation envisaged in Lucchini, they are obliged to treat the violation of EU law as equivalent to the violation of national law and ensure the effectiveness of EU law. ${ }^{62}$ This means that they must make use of the possibilities provided by national law for going back on a judgement with res judicata. ${ }^{63}$ In Impresa Pizzarotti, the national court had indicated that it had the power to go back on the judgement, and the Court held that EU law demanded the application of this power if the judgement was incompatible with EU law. ${ }^{64}$ In this, the Court advocates an EU law friendly interpretation of national rules. This is a method of interpretation commonly used and often applied by the Court.

The crucial question is what happens if the national law is quite explicit in not taking account of ECJ decisions. This is the subject of the recent judgement of the ECJ in Târşia ${ }^{65}$ In Târşia, the plaintiff's claim for recovery of a special tax for motor vehicles had been rejected by the Romanian civil court. After the judgement had become final, the ECJ ruled that this tax was not compatible with EU law. The plaintiff now wants the final judgement to be set aside. Romanian law only allows going back on final judgements in a limited number of cases, three of which are of importance for the

58 S. Schmabl/M. Köber, Durchbrechung der Rechtskraft nationaler Gerichtsentscheidungen zu Gunsten der Effektivität des Unionsrechts?, Europäische Zeitschrift für Wirtschaftsrecht (EuZW) 2010, p. 927 et seq. (929).

59 See also ECJ, Impresa Pizzarotti (fn. 54 ), margin no 61.

60 See, e.g., ECJ, Târșia (fn. 54), margin no 30 et seq.; ECJ, Impresa Pizzarotti (fn. 54), margin no 54.

61 ECJ, Kapferer (fn. 53 ) I-2605, margin no 22. See also Art. 19 para. 1 subpara. 2 TEU: "Member States shall provide remedies sufficient to ensure effective legal protection in the fields covered by Union law.”.

62 ECJ, Târșia (fn. 54), margin no 30.

63 ECJ, Impresa Pizzarotti (fn. 54), margin no 62.

64 ECJ, Impresa Pizzarotti (fn. 54), margin no 64.

65 ECJ, Târșia (fn. 54 ).

EuCLR Vol. 6, 1/2016 
question discussed here: First, the revision of a judgement with res judicata is possible if the Constitutional Court declares a provision that was the subject of the complaint to the Court unconstitutional. Second, it is possible when the ECtHR has found an infringement of human rights and going back on the judgement is necessary to fix it. Third, revision is also possible for final judgements that infringe EU law, but only in administrative proceedings. ${ }^{66}$ However, Romanian law does not allow going back on civil judgements that infringe EU law. The question is whether this complies with the requirements of EU law.

As has been explained above, the rules for going back on a judgement with res judicata need to observe the principles of equivalence and effectiveness, which go effectively hand in hand. It is thus necessary to decide whether those principles demand the application of the above mentioned rules in Romanian Law in the case of incompatibility with EU law. ${ }^{67}$ In his opinion of the Târșia case, AG Jääskinen addresses the issue of whether the Romanian rule for administrative proceedings ought to apply to the civil judgement in question. He states that, although different claims based on the infringement of EU law and national law must be treated equally, this does not include different forms of procedure. ${ }^{68}$ There are good reasons for distinguishing between different forms of judgements for the question of reopening procedures and allowing, for instance, for a more generous revision in the case of criminal law for the benefit of the defendant than in civil law. ${ }^{69}$ The ECJ follows this assessment, thus rejecting a need to apply the rules on revision in administrative proceedings to civil ones. ${ }^{70}$ Accordingly, as revision in administrative proceedings and revision in civil law are not comparable, the principle of equivalence does not demand an equal treatment of civil proceedings.

However, Romanian law also allows the revision in civil proceedings in case of decisions by the ECtHR and the Romanian Constitutional Court. As the question referred to preliminary ruling only concerns the rule on administrative proceedings, the ECJ does not refer to the rules on revision for judgements of the ECtHR and the Romanian Constitutional Court. It only states briefly that "[...] no particular circumstance of the dispute in the main proceedings featured in the case-file available to the Court justifies adopting a different approach [...]"11. Nor did the AG give a detailed opinion on the equivalence of EU law with regard to the other two provisions. Nevertheless, he stated that, in his opinion, "[...] the principle of equivalence is not complied with if a later

66 See the summary of Romanian law in the Opinion of AG Jääskinen, Târșia (fn. 55 ), margin no 7 et seq.

$67 E C J$, Târşia (fn. 54 ), margin no 31 et seq.

68 Opinion of AG Jääskinen, Târșia (fn. 55 ), margin no 49.

69 Opinion of AG Jääskinen, Târșia (fn. 55 ), margin no 50.

70 ECJ, Târșia (fn. 54), margin no 34, 35. It should be noted that the ECJ - consistent with its former jurisprudence - refers the plaintiff Mr. Târșia to the rules on state liability, ECJ, Târșia (fn. 54 ), margin no 40.

71 ECJ, Târșia (fn. 54 ), margin no 39. However, the explicit reference to the circumstances "featured in the case-file" could be interpreted to signify that the Court is aware of the looming question of equivalence with rules that allow a revision in case of Constitutional Court decisions and would have liked to be able to answer it. 
decision of the national Constitutional Court can lead to revision of an earlier final civil judgement [...] when a judgement of the Court [the ECJ] cannot. In such a situation, rights based on the national constitution would enjoy more protection than EU law rights, and thus the latter would not enjoy protection equivalent to that enjoyed by this category of national law-based rights." ${ }^{\prime 2} \mathrm{He}$ adds that the same is true for decisions of the ECtHR. ${ }^{73}$ The meaning of this is clear: national rules that allow exceptions of res judicata in case of decisions of these two types of court but not in case of decisions of the ECJ are not compatible with EU law.

The assessment of AG Jääskinen is correct if ECJ decisions are equivalent to decisions by the ECtHR and the Constitutional Court. However, whether this is the case needs to be determined in detail and by taking account of the actual rules that allow for revision in national law. In this regard, the opinion leaves something to be desired. The statement that national law cannot enjoy better protection than EU law is too superficial because it does not compare the actual exceptions. For example, the type of cases that is decided by the ECtHR does not occur in front of the ECJ. An exception that refers to a specific element of the procedure of one case might not be transferable to EU law. That is why a close analysis of the actual provisions is mandatory.

Nonetheless, the analysis has shown the basic principles of how res judicata is challenged by EU law. Although the Member States are generally not obliged to allow going back on judgements with res judicata, they are obliged to interpret national law in the manner that most complies with EU law. Moreover, if national law recognizes exceptions in case of a conflict of national law with constitutional law or other supreme law, these exceptions must apply to EU law if the situation in EU law is equivalent.

\section{German Law}

German Law has established a special procedure for reopening criminal proceedings that have already been finally concluded by a judgement with the force of res judicata (the so-called "Wiederaufnahmeverfahren"). The procedure is regulated in $\$ \$ 359$ et seq. of the German Code of Criminal Procedure ("Strafprozessordnung", in the following "StPO"). ${ }^{74}$ It applies exclusively to decisions which are endowed with res judicata, so only when no form of appeal is possible. ${ }^{75}$ Thus, the procedure tries to balance the legal certainty achieved by res judicata with a need for justice. Although the whole point of res judicata is to achieve certainty and security and prevent a never-ending tri-

72 Opinion of AG Jääskinen, Târșia (fn. 55 ), margin no 53.

73 Opinion of AG Jääskinen, Târșia (fn. 55 ), margin no 53.

74 An English version of the current German Code of Criminal Procedure is available on the internet: http://www.gesetze-im-internet.de/englisch_stpo/ (last access on 24 October 2015). Unless otherwise indicated, all the English translations of German law are taken from this source.

75 German law knows two types of appellate remedies against judgements, an appeal on points of fact and law ("Berufung") and an appeal on points of law only ("Revision").

EuCLR Vol. 6, 1/2016 
al, in some constellations, in which the final judgement is allegedly unbearably unjust, German law sacrifices these needs on the altar of justice.

This reasoning makes it clear that the procedure has an exceptional character in German Law. Indeed, it is only admissible for specific reasons, most of which are enumerated in $\mathbb{S} 359$ and 362 StPO. These reasons are important for the understanding of the procedure and crucial for the question that is discussed in this paper, namely whether res judicata can be challenged by decisions by the ECJ and ECtHR. Therefore, this paper will start by first explaining the reasons for reopening the procedure (1.) before concentrating on the ECJ/ECtHR question (2.).

\section{Reasons for reopening criminal proceedings}

A main distinction is made between the reopening of procedures for the convicted person's benefit and the reopening to the defendant's detriment. Both are covered by different provisions ( $\mathbb{S} \$ 359$ and $362 \mathrm{StPO}$ ) and are possible for (at least in part) different reasons. German law thus explicitly allows a reopening of procedures after an acquittal in order to achieve a conviction.

a) Reasons for reopening criminal proceedings for the benefit of the convicted person $(\mathbb{} 359 \mathrm{StPO})$

The central provision allowing for a reopening of criminal proceedings is $\$ 359$ StPO. It lists six reasons why criminal proceedings can be reopened. While some of these reasons always lead to a reopening of the trial (nos. 3, 4), others only provide a basis for the reopening if they had an effect on the proceedings that was to the detriment of the defendant (nos. 1, 2, 5, 6). ${ }^{76}$

\section{aa) False or forged documents}

No. 1 allows the reopening of the proceedings if a document that was presented as genuine at the main hearing has subsequently turned out to be false or forged. However, this only provides a reason for the reopening of proceedings under $\$ 359 \mathrm{StPO}$ if the document was used to the detriment of the convicted person. If a false or forged document was used for the benefit of the defendant, it is, however, possible to reopen proceedings to the detriment of the defendant $(\mathbb{} 362$ no. 1 StPO). The majority of scholars define documents as in the crime of forgery $(\mathbb{2 6 7}$ German Criminal Code $=$ "Strafgesetzbuch", in the following "StGB“), i.e. as an embodiment of thought that is meant to and can be used as evidence in legal transactions and whose author is dis-

76 W. Schmidt, in: R. Hannich (ed.), Karlsruher Kommentar zur Strafprozessordnung, 7th ed. $2013, \mathbb{3} 359$, margin no 2 . 
cernible. ${ }^{77}$ Nonetheless, some scholars refer to the definition of documents when used for evidence during trial ( $\$ 249$ StPO), which basically considers a document to be any writing that can be read out. ${ }^{78}$ In any case, it is not necessary that an actual criminal forgery has been committed.

$\$ 364$ sent. 1 StPO contains an important restriction to the reopening of trials, which applies to no.1-3. The application for reopening the trial that is based on a crime having been committed by another person is only admissible if there has been a final conviction for the crime that is the basis for the application of reopening the trial. This means that the trial can only be reopened against the convicted person after - in case of $\$ 359$ no. 2 StPO - the witness or expert who have given false testimony have been tried and judged by a judgement with res judicata. The requirement of a final judgement can be disposed of if there are impediments other than lack of evidence to the trial. Such requirements are, for instance, lack of jurisdiction, the death of the defendant, his unfitness to plead or absence, but also limitation or an amnesty. ${ }^{79}$ Whether or not a reopening of the trial on the basis of another person's offence is possible if the prosecution service has dispensed ${ }^{80}$ with the offence $(\mathbb{S} 153$ et seq. StPO) is disputed among German jurisprudence..$^{81}$ Bearing in mind that there are numerous reasons for dispensing with criminal offences in German law, it is clear that a detailed answer would go beyond the focus of this paper. In any case, the problem is somehow softened by $\$ 359$ no. $5 \mathrm{StPO}$ that has a broader scope than no. 2 and can thus serve as a catchall element in cases where $₫ 364$ StPO forbids the reopening of criminal proceedings. ${ }^{82}$

\section{bb) False testimony or perjury}

According to No. 2, procedures can also be reopened when a witness or an expert who have testified against the convicted person have thereby committed the crime of false testimony or perjury $(\mathbb{S} 153-155,161 \mathrm{StGB})$. In contrast to no. 1 , it is necessary that the witness or expert must be criminally responsible, i.e. all elements of crime need to

77 G. Pfeiffer, Strafprozessordnung, 2005, \359, margin no 2; Schmidt (fn. 76), \359, margin no 5; T. Singelnstein, in: J. P. Graf (ed.), Beck’scher Online-Kommentar Strafprozessordnung, 22nd edition, (date: 1.9.2015), $\$ 359$, margin no 9.

78 See, for further discussion and background, H. Frister, in: J. Wolter (ed.), Systematischer Kommentar zur Strafprozessordnung, $4^{\text {th }}$ edition, 2014, Vol. 7, $\$ 359$, margin no 16 et seq.

79 Schmidt (fn. 76 ), $\$ 364$, margin no 6; Singelnstein (fn. 77 ), $\$ 364$, margin no 1.

80 In German law, criminal proceedings are governed by the legality principle, $\mathbb{\$} 152$ para. 2 StPO. However, there are numerous exceptions when the Prosecution Service can refrain from bringing a charge against the suspect, for example in case of petty offences ( $\mathbb{1} 153 \mathrm{StPO})$ or when the suspect agrees to certain conditions, e.g. the payment of a fine ( $\$ 153 \mathrm{a}$ StPO). This gives the Prosecution Service a certain amount of discretion.

81 See e.g. the contrasting opinions of $K G$, BeckRS 2009, 25384 and OLG Düsseldorf, Goltdammer's Archiv (GA) 1980, 393.

82 Cf. also $\$ 364$ sent. 2 StPO; Frister (fn. 78 ), $\$ 359$, margin no 6, who, nevertheless, points out that $₫ 364$ StPO can become relevant for $\$ 359$ no. 3 StPO.

EuCLR Vol. 6, 1/2016 
be established. ${ }^{83}$ This also applies to guilt. Therefore, a reopening of the trial is not possible if, for example, the witness has not reached the minimum age for criminal responsibility ${ }^{84}$ or the witness was not criminally responsible for other reasons. ${ }^{85}$

\section{cc) Breach of official duty by a judge}

No. 3 bears similarities to no. 2, but refers to the judges and lay judges that were involved in the proceedings that are now to be reopened. If one of these persons has breached his or her official duties in relation to the case and thus committed a crime, the reopening is admissible. Breaches of duty by other officials are not included in no. $3 .{ }^{86}$ As with no. 2, it is necessary that the conduct of the judge or lay judge amounts to a criminal offence. Possible offences are, for instance, unlawful imprisonment $(\mathbb{2} 239 \mathrm{StGB})$, taking bribes for violating an official duty ( $\$ 332 \mathrm{StGB})$ and perverting the course of justice ( $\$ 339$ StGB) $\cdot{ }^{87}$ No. 3 is absolute in the sense that it is not necessary to prove that the criminal offence committed by the judge or lay judge had any effect on the outcome of the trial. However, according to $\$ 364$ sent. 1 StPO a final conviction of the judge or lay judge is necessary. Moreover, no. 3 does not apply in cases where the convicted person has caused the judge's or lay judge's violation of his or her official duty.

dd) Annulment of a different judgement

No. 4 allows the reopening of criminal proceedings "if a civil court judgement on which the criminal judgement is based is quashed by another final judgement" ${ }^{88} \mathrm{Al}$ though no. 4 only refers to civil court judgements and thus to civil matters, the general opinion is that judgements on any matter apart from the criminal one fall within the ambit of no. $4 .^{89}$ The more interesting question is when a criminal judgement is based on another judgement. Generally, judgements are not binding in German law. For instance, $\mathbb{} 262$ para. 1 StPO stresses that the criminal court is not bound by a decision of the civil court. ${ }^{90}$ This can lead to the perverse situation that a person is convicted for theft by the criminal court although the civil court has held that the person was, in

83 Schmidt (fn. 76 ), $\ 359$, margin no 12; Singelnstein (fn. 77 ), $\ 359$, margin no 12.

84 OLG Hamburg (Higher Regional Court Hamburg), Neue Juristische Wochenschrift (NJW) 1969, 2159.

85 See KG ("Kammergericht" = Superior Court of Berlin), Beck Rechtsprechung (BeckRS) 2009, 22706 on the defence of duress ("Nötigungsnotstand").

86 Frister (fn. 78 ), $\$ 359$, margin no 26.

87 Cf. the longer list in Singelnstein (fn. 77 ), $\$ 359$, margin no 15.

88 In German: „wenn ein zivilgerichtliches Urteil, auf welches das Strafurteil gegründet ist, durch ein anderes rechtskräftig gewordenes Urteil aufgehoben ist“.

89 Schmidt (fn. 76 ), $\$ 359$, margin no 15; Singelnstein (fn. 77 ), $\mathbb{3} 359$, margin no 18; Pfeiffer (fn. 77 ), $\$ 359$, margin no 5 .

90 Nonetheless, some judgements are binding, especially those defining the person's status such as divorce judgements. See J.-D. Kuckein, in: R. Hannich (ed.), Karlsruher Kommentar zur Strafprozessordnung, 7 th edition, $2013, \mathbb{2} 262$, margin no 4 et seq. 
fact, the owner of the stolen property. It follows that no. 4 does not require that the criminal court felt bound by the judgement, but that it suffices if the former judgement has been introduced as evidence. ${ }^{91}$

\section{ee) New facts or evidence}

No. 5 contains without doubt the most important reason for reopening criminal proceedings in practice. It allows a reopening "if new facts or evidence were produced, which, independently or in connection with the evidence previously taken, tend to support the defendant's acquittal or, upon application of a less severe penal norm, a lesser sentence or a fundamentally different decision on a measure of reform and prevention ". ${ }^{92}$ Therefore, in order to justify a reopening, three requirements must be met: first, there must be facts or evidence, second, the facts or evidence must be new and, third, they must be suited for justifying a more positive outcome of the trial.

Facts are more or less anything that can be proven..$^{93}$ They can refer to the factual basis of the case, the quality of the evidence or procedural requirements. ${ }^{94}$ However, facts are not law. Accordingly, legal mistakes or a change of law or jurisprudence are not facts and thus do not give rise to a reopening of criminal proceedings under no. 5. ${ }^{95}$ Nor are legal opinions and values facts in the sense of $\$ 359$ no. 5 StPO. No. 5 thus only applies if the factual basis of the judgement has been shattered. ${ }^{96}$ The distinction between facts and law can be tricky. For instance, a classical situation for reopening the trial is a violation of the ne bis in idem principle. ${ }^{97}$ In this case, the new fact is the realization that the facts had already been adjudicated. ${ }^{98}$ However, the important part of this realization is its legal implication, namely that there was a procedural impediment to the second trial.

The term "evidence" refers to the types of evidence that are admissible for proving the guilt of the defendant. ${ }^{99}$ These are witnesses, experts, documents and inspection. ${ }^{100}$

91 Schmidt (fn. 76), $\$ 359$, margin no 16.

92 In German: “wenn neue Tatsachen oder Beweismittel beigebracht sind, die allein oder in Verbindung mit den früher erhobenen Beweisen die Freisprechung des Angeklagten oder in Anwendung eines milderen Strafgesetzes eine geringere Bestrafung oder eine wesentlich andere Entscheidung über eine Maßregel der Besserung und Sicherung zu begründen geeignet sind".

93 Singelnstein ( $\mathrm{fn} .77$ ), $\$ 359$, margin no 20.

94 Schmidt (fn. 76 ), $\$ 359$, margin no 17.

95 Exceptions are contained in $\$ 359$ no. $6 \mathrm{StPO}$ and $\$ 79$ para. 1 of the Federal Constitution Court Act ("Bundesverfassungsgerichtsgesetz"). See below III. 1. C), p. 27.

$96 B G H$ (Federal Supreme Court), Neue Juristische Wochenschrift (NJW) 1993, 1481 (1482); Schmidt (fn. 76), \$359, margin no 19.

97 See Schmidt (fn. 76 ), $\$ 359$, margin no 20.

98 Not precise enough Schmidt (fn. 76 ), $\$ 359$, margin no 20.

99 Pfeiffer (fn. 77 ), $\$ 359$, margin no 7.

100 German criminal procedure knows two standards of evidence: For questions of guilt, only the above mentioned evidence is accepted (so-called "Strengbeweisverfahren"). For other questions, such as procedural requirements, all types of evidence are admitted (so-called "Freibeweisverfahren").

EuCLR Vol. 6, 1/2016 
It should be noted that evidence is the actual person, not his or her statement. ${ }^{101}$ Thus, if a witness changes his or her statement, this is not new evidence, but new facts. The defendant's pleading is not regarded as evidence in German criminal procedure. This is because $\$ 244$ para. 1 StPO states that the evidence is taken after the examination of the defendant. Nonetheless, the defendant's pleading plays an important role in the evaluation of the facts and is thus not different from evidence.

Facts and evidence are new when they have not been taken into consideration by the court at the time of the trial. ${ }^{102}$ This means that it is not necessary that a fact or evidence has occurred after the final decision in order to be regarded as new. Rather, a fact can also be new when it should have been taken into consideration, but mistakenly was not. ${ }^{103} \mathrm{~A}$ fact can be new even if the defendant did not disclose it on purpose, thus making it impossible for the court to take the fact into account. The same is true for new evidence. According to $\$ 364$ sent. 2 StPO, the strict rule in sent. 1 on the allegation of a criminal offence does not apply in the context of $\$ 359$ no. 5 StPO. This means that the reopening of criminal proceedings can be based on the suspicion of a criminal offence by e.g. a witness as new fact, even if the witness has not been prosecuted for false testimony.

The new facts or evidence must have a certain quality: they must be suitable for justifying an acquittal, a lesser sentence due to the application of a less severe offence or a fundamentally different decision on a measure of reform and prevention ("Maßregel der Besserung und Sicherung"). The latter are measures that are applied in addition to or instead of a criminal sentence for reasons of preventing danger to the society and others, such as disqualification from driving ( $\$ 69$ StGB). ${ }^{104}$ Although $₫ 359$ no. 5 StPO does not specify what kind of different decision is required, it is clear from the context that it must be a decision that is beneficial for the defendant. ${ }^{105}$ Moreover, although only explicitly stated in no. 5, the goals are considered to apply to all reasons for reopening criminal proceedings for the benefit of the convicted person. ${ }^{106}$ However, $\$ 363$ StPO contains two explicit restrictions to the goals that can be achieved by the reopening procedure: The procedure is not admissible for the purpose of imposing a different sentence on the basis of the same penal law (para. 1) or for the purpose of achieving a mitigated sentence because of diminished responsibility (para. 2; see also $\$ 21 \mathrm{StGB}) \cdot{ }^{107}$

In order to be relevant for justifying a change for the better (from the defendant's perspective), the new facts generally need to be able to influence the judgement in a

101 Singelnstein (fn. 77), $§ 359$, margin no 22.

102 Singelnstein (fn. 77), $\$ 359$, margin no 24.

$103 B \operatorname{VerfG}$ („Bundesverfassungsgericht“ = German Federal Constitutional Court), Neue Juristische Wochenschrift (NJW) 2007, 207 (208).

104 A comprehensive list of the measures of reform and prevention in German law can be found in $\$ 61 \mathrm{StGB}$.

105 See also Singelnstein (fn. 77 ), $\$ 359$, margin no 32; Schmidt (fn. 76 ), $\$ 359$, margin no 36.

106 Schmidt (fn. 76), $\$ 359$, margin no 4.

107 See on problems with this provision S. Stern, Zur Verteidigung des Verurteilten in der Wiederaufnahme, Neue Zeitschrift für Strafrecht (NStZ) 1993, p. 409 et seq. (410 et seq.). 
positive way and must, in the concrete case, show enough promise of a positive decision. ${ }^{108}$

\section{ff) Violation of the ECHR}

$\$ 359$ no. $6 \mathrm{StPO}$ is a fairly new addition to the list of reasons for reopening the proceedings. It was added in $1998^{109}$ in order to allow compliance with the ECHR. Formerly, German criminal judgements with res judicata could not be changed if there had been a violation of the ECHR. ${ }^{110}$ No. 6 allows the reopening

"if the European Court of Human Rights has held that there has been a violation of the European Convention on the Protection of Human Rights and Fundamental Freedoms or of its Protocols and the judgement was based on that violation". 111

The first requirement, the judgement by ECtHR, is certainly met when the exact proceedings are to be reopened that have led to a violation of the ECHR. ${ }^{112}$ This is the situation that was envisaged by the German legislator. ${ }^{113}$ Whether or not $\ 359$ no. 6 StPO also applies when the ECtHR has decided in a different case that concerns the same kind of problem is under debate. A similar question is whether a reopening is possible without a decision by the ECtHR in case of an obvious violation of the ECHR. ${ }^{114}$ These questions will be covered further below (under 2.).

The second requirement is that the judgement must have been based on the violation of the ECHR. The wording of $\$ 359$ no. 6 StPO refers to $\$ 337$ para. 1 StPO, which states that the appeal on points of law ("Revision") is only possible if the judgement was based on a violation of law. ${ }^{115}$ However, this does not mean that the applicant must prove the causation between the violation of the ECHR and the judgement. It suffices that it was possible that the violation of the ECHR has affected the judgement. ${ }^{116}$ Accordingly, causation is only excluded if it was clear that the violation of the ECHR had no impact on the judgement. This can happen if the violation is of a nature that cannot affect the judgement or if it has been healed in future proceedings. ${ }^{117}$

108 Singelnstein (fn. 77), $\$ 359$, margin no 30 .

109 By the Gesetz zur Reform des strafrechtlichen Wiederaufnahmerechts, Bundesgesetzblatt (Federal Official Journal) I 1998 Nr. 44, 1802.

110 See $B \operatorname{VerfG}$, Neue Juristische Wochenschrift (NJW) 1986, 1425.

111 Translation taken from http://www.gesetze-im-internet.de/englisch_stpo/ (last access on 21 November 2015).

112 Schmidt (fn. 76 ), $\$ 359$, margin no 40.

113 BT Drs. („Bundestag Drucksache“ = Official Documents of the German Parliament) $13 / 10333$, p. 4.

114 Pro LG Ravensburg (District Court Ravensburg), Neue Zeitschrift für Strafrecht - Rechtsprechungsreport (NStZ-RR) 2001, 115 (116).

115 See also BT Drs. 13/10333, p. 5.

116 J. Gericke, in: R. Hannich (ed.), Karlsruher Kommentar zur Strafprozessordnung, 7th edition, 2013, $\$ 337$, margin no 33 et seq.

117 BT Drs. 13/10333, p. 4.

EuCLR Vol. 6, 1/2016 
An example for the need for causation is the Gäfgen case ${ }^{118}$, which is one of the best-known recent criminal cases in Germany: Gäfgen was suspected of having kidnapped a child, but refused to divulge the child's abode when interrogated. Out of fear for the child' life, the vice president of the police department Daschner ordered to threaten Gäfgen that a police expert would cause him "unbearable pain" if he did not cooperate. This led to Gäfgen confessing the murder of the child. As this method of interrogation qualifies as torture and is thus illegal under German law, the confession was not used as evidence in trial (see $\$ 136 \mathrm{a}$ StPO) and the executing police officers were punished. Gäfgen was convicted for murder in an especially serious case with a minimum sentence of 25 years of imprisonment. Trying to achieve the reopening of criminal proceedings, Gäfgen applied to the ECtHR. The Court held that the threat amounted to inhumane treatment (Art. 3 ECHR), but stated that the violation of Art. 3 ECHR had not affected the criminal proceedings to such an extent as to warrant a reopening. ${ }^{119}$ This was due to the fact that the defendant had confessed a second time during the main oral procedure without being under duress. Not surprisingly, the German courts shared the assessment of the ECtHR and refused a reopening for lack of causation. ${ }^{120}$

The matter of causation must always be addressed in reopening proceedings based on $₫ 359$ no. $6 \mathrm{StPO}$, even if the impact of the violation on the judgement is obvious. ${ }^{121}$ In this, the reopening procedure differs from the appeal on points of law: In the latter proceedings, causation between a violation of law and the judgement is assumed in a number of specified cases (see $\$ 338 \mathrm{StPO}$ ). These are the so-called absolute reasons for an appeal on points of law ("absolute Revisionsgründe"). Accordingly, if the court finds one of these violations, the judgement is quashed without any further consideration of the impact of the violations. This is not so in the reopening procedure, even if the reasons for reopening are the same that would allow the assumption of causation in the appeal procedure. ${ }^{122}$ The reason is that the reopening procedure is not considered to serve the correctness of the criminal procedure, but substantive justice. ${ }^{123}$

A reopening that is based on $₫ 359$ no. $6 \mathrm{StPO}$ also needs to pursue the objectives named in no. 5 , i.e. an acquittal, the reduction of the sentence or a more positive decision on a matter of reform and prevention. ${ }^{124}$ This is of great importance because German law compensates an over-long duration of criminal proceedings (see art. 6 para. 1 ECHR) by assuming part of the sentence to be already enforced (so-called "Voll-

118 European Court of Human Rights (ECtHR), G. v. Germany, Application no. 22978/05, Judgement 10 June 2010.

119 ECtHR, G. v. Germany (fn. 118 ), margin no 191.

120 OLG Frankfurt, Beck Rechtsprechung (BeckRS) 2012, 15152.

121 OLG Stuttgart, Neue Juristische Wochenschrift (NJW) 2000, 243 (243f.).

122 OLG Stuttgart, NJW 2000, 243 (244).

123 OLG Stuttgart, NJW 2000, 243 (244).

124 OLG Celle, Neue Zeitschrift für Strafrecht - Rechtsprechungsreport (NStZ-RR) 2010, 251 (252). 
streckungslösung”). ${ }^{125}$ A reduction of a sentence as compensation is, however, not considered to be an admissible objective of reopening procedures. ${ }^{126}$ As a result, even though a violation of the ECHR has occurred that normally would give rise to a reduced sentence, a change of sentence is not possible.

b) Reasons for reopening criminal proceedings to the detriment of the defendant $(\mathbb{S} 362 \mathrm{StPO})$

The reasons that are contained in the first three numbers are similar to those contained in $\ 359$ no. 1-3 StPO. The only difference is that $\$ 362$ no. 3 StPO also applies if the violation was caused by the defendant. That the exception that was contained in $\$ 359$ no. $3 \mathrm{StPO}$ is missing in $\$ 362 \mathrm{StPO}$ makes sense: $\mathbb{} 362$ StPO applies to the reopening of criminal proceedings to the detriment of the defendant. If the defendant has caused the criminal violation by the judge, there is even more reason to allow the reopening of criminal proceedings to his or her detriment.

No. 4 allows the reopening of criminal proceedings if the acquitted person has confessed the criminal offence. This only applies in the case of a complete acquittal, not if, e.g., the defendant has been convicted of a lesser crime and then confesses a more serious one. For example, if the defendant has been convicted for negligent manslaughter and then confesses a murder, a reopening is not possible. A confession means that the defendant must admit the facts and his involvement. ${ }^{127}$ It is also important that the confession occurs after the court has gathered the facts. ${ }^{128}$ Moreover, the confession needs to be credible. The court has to decide on credibility by applying life experience and ideas on probability. ${ }^{129}$

As with $₫ 359$ StPO, $\int 363$ StPO applies. Therefore, it is not possible to apply for the reopening of proceedings to the detriment of the defendant in order to gain a higher sentence for the same offences. This is not relevant for $\$ 362$ no. 4 StPO because this number applies only to acquitted persons, but it can be relevant for $\mathbb{} 362$ no. 1-3 StPO.

\section{c) Violation of the Basic Law ("Grundgesetz”)}

The Federal Constitutional Court Act ("Bundesverfassungsgerichtsgesetz", in the following "BVerfGG") contains a special rule on the reopening of criminal proceedings which is important in the context of this paper. $\$ 79$ BVerfGG reads in the first paragraph:

$125 B G H-$ Großer Senat (Grand Chamber for Criminal Matters), BGHSt (Official Collection of Decisions in Criminal Matters) 52, 124 (134 ff.).

126 OLG Celle, NStZ-RR 2010, 251 (252).

127 Schmidt (fn. 76 ), $\$ 362$, margin no 11 .

128 This means that the confession can occur before the appeal on points of law ("Revision"), see Schmidt (fn. 76 ), $\$ 362$, margin no 18.

129 Singelnstein (fn. 77 ), $\$ 362$, margin no 7.

EuCLR Vol. 6, 1/2016 
"New proceedings may be instituted in accordance with the provisions of the Code of Criminal Procedure against a final conviction based on a rule which has been declared incompatible with the Basic Law or null and void in accordance with Article 78 above or on the interpretation of a rule which the Federal Constitutional Court has declared incompatible with the Basic Law." 130

This paragraph 1 is an exception to the general rule on consequences of Federal Constitutional Court ("Bundesverfassungsgericht") decisions. In general, the decision that a law is void or incompatible with the Basic Law, the German Constitution, does not affect final decisions. Exceptions are cases in which the individual that is affected by the decision has applied to the Constitutional Court, e.g. by lodging a constitutional complaint ("Verfassungsbeschwerde", see $\ 95$ BVerfGG). ${ }^{131}$ However, final decisions that are based on a void norm and have not yet been enforced cannot be enforced in the future.

Nonetheless, this rule is broken for criminal convictions: If a conviction is based on a rule that is null and void or incompatible with the Constitution or an interpretation that is incompatible with the Basic Law, the criminal proceedings can be reopened according to the procedure contained in the Code of Criminal Procedure. In this, $\mathbb{\$} 79$ para. 1 BVerfGG resembles $₫ 359$ no. 6 StPO. ${ }^{132}$ As $\ 79$ para. 1 BVerfGG refers to the German Code of Criminal Procedure, it can thus be described as actual no. 7 to $\$ 359$ StPO. ${ }^{133}$

A rule is void if it violates the Basic Law ( $\$ 78$ BVerfGG). This is the classical consequence of incompatibility with higher ranking law in the German legal order. However, over the years the Federal Constitutional Court has developed a second form of judgement. Instead of declaring a rule to be null and void, it can hold a rule to be incompatible with the Constitution. The reasons for this are practical: $\$ 35$ BVerfGG allows the Court large discretion on the enforcement of its judgements. If a rule has only been declared incompatible with the Basic Law, the Court can order it to still be applicable until the legislator has changed the law. ${ }^{134}$ This is often done in cases of discrimination. ${ }^{135}$ In any case, both forms of decisions mean that criminal convictions cannot be based on them. Decisions by the Federal Constitutional Court are the only deci-

130 Translation by Inter Nationes, available at: http://www.iuscomp.org/gla/statutes/BVerfGG.htm\#79 (last access on 24 October 2015).

131 H. Bethge, in: T. Maunz/B. Schmidt-Bleibtreu/F. Klein/H. Bethge, BVerfGG, 44th installment (July 2014), $\$ 79$, margin no 4 et seq. See also M. Graßhof, Auswirkungen der neuen Sitzblockade-Entscheidung des BVerfG

Wiederaufnahme aller bisherigen Verfahren oder nur der nach der ersten verfassungsgerichtlichen Entscheidung ergangenen Strafurteile?, Neue Juristische Wochenschrift (NJW) 1995, p. 3085 et seq. (3088).

132 Bethge (fn. 131 ), $\$ 79$, margin no 25.

133 Bethge (fn. 131 ), $\$ 79$, margin no 25. See also, on the reference to the Code of Criminal Procedure, K. Bajobr, Die Aufhebung rechtsfehlerhafter Strafurteile im Wege der Wiederaufnahme, 2008, pp. 38.

134 H. Bethge, in: T. Maunz/B. Schmidt-Bleibtreu/F. Klein/H. Bethge, BVerfGG, 41st installment (July 2013), $\$ 78$, margin no 65 et seq.

135 Bethge (fn. 134 ), $\$ 78$, margin no 69. 
sions in German law that are binding for other Courts ( $\$ 31$ BVerfGG). In fact, this type of judgement is even endowed with legislative force ( $\$ 31$ para. 2 BVerfGG).

The third situation that allows the reopening of the criminal proceedings is a decision that a certain interpretation of a rule is incompatible with the Constitution. This is a less severe form of judgement which keeps the legal rule intact and is very common before the Federal Constitutional Court. ${ }^{136}$ The Court holds that a legal provision complies with the Constitution if it is interpreted in a usually restrictive manner. Criminal convictions that were based on the former, more extensive interpretation can thus be reopened. ${ }^{137}$

Although $₫ 79$ para. 1 BVerfGG refers to legal rules in general, it is commonly interpreted to solely apply to substantive criminal law provisions. ${ }^{138}$ Procedural rules are thus supposed to be excluded from the scope of $\$ 79$ para. 1 BVerfGG. The reason for this narrow interpretation is that the exceptional character of $\$ 79$ BVerfGG makes it necessary to reserve it for the most grievous cases, i.e. those where the criminal law provision that forms the basis of the judgement violates the Basic Law. ${ }^{139}$ However, it can be just as bad if a conviction is based on evidence that has been gathered in a way that was unconstitutional due to a violation of fundamental rights. ${ }^{140}$ In this respect, it is not convincing to restrict $\$ 79$ para. 1 BVerfGG to substantive criminal law. ${ }^{141}$ As with $₫ 359$ no. 6 StPO, the judgement must have been based on the rule that is declared void or incompatible or whose interpretation is contested.

$\$ 79$ para. 1 BVerfGG does not specify whether it only applies for the benefit of the defendant or to his or her detriment. ${ }^{142}$ In contrast to the English translation cited above, the German version does not speak of a "final conviction" but uses the neutral term "final judgement" ("rechtskräftiges Strafurteil") that encompasses either a positive or a negative judgement. However, there are several reasons why the translation is nonetheless correct in restricting $\$ 79$ para. 1 BVerfGG to the reopening for the benefit of the convicted person. First, it is difficult to imagine a case in which a criminal judgement is based on void rule and proceedings are reopened to the detriment of the defen-

136 See Graßhof, NJW 1995, p. 3085 et seq. (3086).

137 There are several problems attached to this. First, an interpretation that is compatible with the Constitution is often not part of the operative part of the judgement and can thus not become binding in accordance with $₫ 31$ para. 2 BVerfGG. Second, while it is the Federal Constitutional Court's prerogative to decide on whether or not a legal rule is void and null or incompatible, any court is asked to interpret legal norms with regard to the Constitution. However, a reopening of criminal proceedings is only possible after a decision of the Constitutional Court, not of other Courts such as the Federal Supreme Court ("Bundesgerichtshof”). See Bethge (fn. 131 ), $\$ 79$, margin no 34 et seq.

138 BVerfGE (Official Collection of Decisions by the Constitutional Court) 11, 263 (265); Bethge (fn. 131), $\mathbb{\$} 79$, margin no 36; R. Hannich, in: R. Hannich (ed.), Karlsruher Kommentar zur Strafprozessordnung, 7th edition, 2013, Vor $\$ \$ \$ 359 \mathrm{ff}$., margin no 24. Different Bajobr (fn. 133), pp. 66; Singelnstein (fn. 77), \359, margin no 36.

139 BVerfGE 11, 263 (265).

140 Bajohr (fn. 133), p. 67 et seq.

141 See Bajohr (fn. 133), p. 68; Singelnstein (fn. 77), \359, margin no 36.

142 See also Hannich (fn. 138 ), Vor $\$ \$ 359$ ff., margin no 18.

EuCLR Vol. 6, 1/2016 
dant. This would mean that the defendant must have been acquitted or at least partially acquitted on the basis of a void criminal provision. These sorts of cases are possible if, for instance, a particular defence is found to be void and null. ${ }^{143}$ However, it is unconceivable how a criminal conviction could be obtained after reopening the proceedings. Even assuming that this does not count as retroactive application of criminal law (see Art. 103 para. 2 Basic Law), the defendant would be blameless for a mistake of law. ${ }^{144}$ In addition, the comparison of $\$ 79$ para. 1 BVerfGG and para. 2 supports the interpretation that $\$ 79$ BVerfGG applies only for the benefit of the defendant. According to $\$ 79$ para. 2 sent. 2 BVerfGG, judgements that are based on a provision that breaches the Constitution cannot be enforced. This refers to public law in a broad sense, i.e. to enforcement of state decisions. ${ }^{145}$ It follows that $\$ 79$ para. 1 BVerfGG also refers to decisions that are enforceable. These cannot be acquittals, but must be convictions. Accordingly, $\$ 79$ para. 1 BVerfGG only allows a reopening for the benefit of the defendant. ${ }^{146}$

\section{ECJ and ECtHR decisions and the reopening of criminal proceedings}

Having examined the reasons for reopening criminal proceedings in German law, the question remains whether the reopening of criminal proceedings is possible in the four scenarios identified above. ${ }^{147}$ The main issue is whether these scenarios provide a sufficient reason for reopening the procedure.

\section{a) Judgement by the ECtHR in the same case}

In the first scenario, when the ECtHR has rendered a decision on the exact matter that was part of the national judgement, the solution is, at first glance, simple: $₫ 359$ no. 6 StPO explicitly recognizes a reason for reopening procedures for the benefit of the convicted person if the ECtHR has held that the ECHR has been violated by the national decision. However, at second glance it becomes clear that a reopening is not possible in all cases where the ECtHR has held a violation to have taken place. The national judgement must also be based on the violation of the ECHR. This is the case if the judgement would have been different if the violation of the ECHR had not occurred. This leads to the question of whether such a limited admissibility of the reopening procedure conforms to the ECHR.

143 See the Constitutional Court decision about the so-called "Mauerschützen" - soldiers that were asked to shoot in order to prevent people from crossing the border between East and West Germany, BVerfGE 95, 96.

144 See on the German concept of mistakes F. Meyer, in: M. Böse/F. Meyer/A. Schneider (eds.), Conflicts of Jurisdiction in Criminal Matters in the European Union, Vol. 1, Baden-Baden 2013, pp. 141 (171 et seq.).

145 Bethge (fn. 131$), \$ 79$, margin no 80.

146 Different Hannich (fn. 138 ), Vor $\$ \$ 359$ ff., margin no 18.

147 See I. 1., 2. 
The ECHR contains a provision that obliges the Contracting Parties to follow the decisions by the ECtHR in all cases to which they are parties (Art. 46 para. 1 ECHR). However, the Convention explicitly allows for monetary compensation ("just satisfaction") in cases where national law allows only partial reparation for the violation (Art. 41 ECHR). It follows that it is acceptable if a Contracting Party cannot provide complete reparation. In the light of this, it is admissible that German criminal law only allows for a reopening of procedures if the violation could have had an effect on the judgement. The ECtHR actually uses a similar test when ascertaining whether the fair trial principle has been violated: a violation can be "healed" if the procedure is fair overall. ${ }^{148}$ Accordingly, with reference to the exact cases that were part of the ECtHR decision, the German rule complies with the ECHR. ${ }^{149}$

\section{b) Judgement by the ECtHR in a different case}

The second scenario is more difficult to determine for German law. What happens to similar cases if the ECtHR has found a violation in one situation?

\section{aa) Judgements that are not binding under Art. 46 ECHR}

The first question is whether $\$ 359$ no. 6 StPO also includes judgements that are not binding under Art. 46, e.g. because they concern other Contracting Parties. This needs to be determined by interpretation of the provision using the four recognized interpretation methods (textual, historical, systematic and teleological).

The text of the provision is ambiguous. It requires a judgement by the ECtHR that has found a violation of the ECHR. The German judgement must have been based on this violation. The "this" could refer either to the exact violation that was part of the judgement by the ECtHR or to any violation of a similar kind. $\$ 359$ no. 6 StPO thus does not exclude an extensive interpretation. ${ }^{150}$

However, looking at the legislative process, it becomes clear that the German legislator did not intend $\$ 359$ no. 6 StPO to apply to judgements in different cases. At the same time when the introduction of $\$ 359$ no. $6 \mathrm{StPO}$ was discussed, it was suggested to include an addition to the text that said: "This also applies if a federal German law or a similar law in the legal order of a Contracting Party of the European Convention

148 See, e.g., B. Valerius, in: J. P. Graf (ed.), Beck'scher Online-Kommentar Strafprozessordnung, 20th edition, (date: 15.1.2015), Art. 6 EMRK margin no 16.

149 Cf. $B \operatorname{VerfG}$, NJW 1986, 1425 (1426).

150 However, many German scholars seem to think that an extensive interpretation is not possible and that an analogy to the provision would have to be formed. See, e.g., Schmidt (fn. 76), $\$ 359$, margin no 40 .

EuCLR Vol. 6, 1/2016 
of Human Rights has been found to be contradicting the Convention." 151 This was refused because the binding effect of judgements is restricted to the parties of the case (Art. 46 ECtHR). ${ }^{152}$ Clearly, the legislator did not intend the new $\$ 359$ no. 6 StPO to comprise precisely those situations that were to be excluded. The legislative history thus suggests a restrictive interpretation.

This is supported by the systematic interpretation. It has been explained before that the reopening procedure is an extraordinary remedy and that the reasons for allowing the reopening are limited for good reasons. ${ }^{153}$ Following this approach, it is logical to interpret these reasons in a rather restrictive way, thus limiting the options for challenging res judicata. In this respect, it becomes clear that the idea of the legislator is to restrict the reopening procedure to those convicted persons that have actually filed a complaint before the ECtHR. ${ }^{154}$ The Higher District Court Bamberg, having to decide on the admissibility of a reopening procedure based on judgements that concerned a different applicant, thus stated that $\$ 359$ no. $6 \mathrm{StPO}$ was not to be interpreted in a wide manner in order to "spare" the applicant from applying to the ECtHR, but that the applicant could be expected to bring his case before the ECtHR if he desired a reopening of proceedings. ${ }^{155}$ This means that the reopening procedure is reserved for those that have actively sought a decision by the Court. This argument is supported by the consideration that an individual complaint can only be filed within six months after a final decision (Art. 35 para. $1 \mathrm{ECHR}$ ) and that this strict period could be undermined if the reopening of criminal proceedings would be accepted in different cases. ${ }^{156}$

The question remains whether a more extensive interpretation fits the purpose of the law (its telos) better than a restrictive one. The purpose of $\$ 359$ no. 6 StPO is to enhance compliance with the ECHR. ${ }^{157}$ It is deemed to be a symbol of the positive attitude of Germany towards the ECHR if the state allows for a reopening of criminal procedures in cases where a violation has explicitly been held. ${ }^{158}$ This positive attitude would, of course, also be underlined by the recognition of different judgements. However, it must be noted that the reopening of criminal proceedings after an actual conviction of the German state by the ECtHR is much more important for showing appreciation of the ECHR than the recognition of judgements against other Contracting

151 Translation by the author. The German version is: „Dies gilt auch, wenn die Konventionswidrigkeit einer bundesdeutschen Rechtsnorm oder einer deren Regelungsinhalt entsprechenden Rechtsnorm eines anderen Signaturstaates der Europäischen Konvention zum Schutze der Menschenrechte und Grundfreiheiten festgestellt wurde." See BT Drs. $13 / 10333$, p. 3.

152 BT Drs. 13/10333, p. 4. Actually, this is a rather weak argument: of course, the German legislator could decide to take these decisions into account as a reason for reopening criminal proceedings, even if this is not obligatory. The ECHR does not forbid a further commitment.

153 See III.

154 See OLG Bamberg, Beck Rechtsprechung (BeckRS) 2013, 05389.

155 OLG Bamberg, BeckRS 2013, 05389.

156 Bajobr (fn. 133 ), p. 89.

157 See BT Drs. 13/10333, p. 3.

158 BT Drs. 13/10333, p. 3. 
Parties. Differing between those two types of judgements can thus be justified. Moreover, as has been explained above, the ECHR and the ECtHR do not generally oblige the Contracting Parties to reopen proceedings on the basis of decisions in which they did not participate. Compliance with the ECHR is not dependent on the inclusion of any judgement in $\$ 359$ no. 6 StPO. Accordingly, $\$ 359$ no. 6 StPO does not have to be interpreted in a broader manner. ${ }^{159}$

\section{bb) Pilot-judgement procedure}

However, the result is different for pilot-judgement procedures. As has been explained above, pilot-judgement procedures are based on the idea that the Contracting Party uses the ECtHR judgement as a prototype for dealing with a number of similar cases. ${ }^{160}$ If the ECtHR decides in the pilot-judgement that the reopening of similar procedures is the best, or even the only, way to offer redress, the Contracting Party must be able to do so. ${ }^{161}$

As has been seen, $\$ 359$ no. 6 StPO generally requires a decision of the ECtHR on the same matter. On the contrary, the pilot-judgement procedure is based on the idea that one case is taken to serve as a model for all similar applications. For the purpose of $\$ 359$ no. $6 \mathrm{StPO}$, it is thus important what happens to the similar applications after a pilot judgement has been rendered. Rule 61 only explains that the ECtHR is free to adjourn the cases or to go on examining them. If the matter is not resolved, the Court shall restart examining cases (rule 61 para. 8). But what happens to the applications if the Contracting Party is willing to resolve the matter? The ECtHR has invented different ways of dealing with similar applications, among them the declaration of inadmissibility for lack of exhausting domestic remedies (Art. 35 para. 1 ECHR), lack of disadvantage (Art. 35 para. 3 lit. b ECHR) or because the application is manifestly ill-founded in light of the new remedies adopted by the Contracting Party (Art. 35 para. 3 lit. a ECHR) and the striking out of applications (Art. 37 ECHR), also after friendly settlements (Art. 39 ECHR) or unilateral declarations. ${ }^{162}$

With regard to $\$ 359$ no. $6 \mathrm{StPO}$, both the declaration of inadmissibility and the strike out are problematic. A declaration of inadmissibility, for whatever reason, does not hold that there has been a violation of the ECHR. Accordingly, it cannot form the basis of a reopening procedure under $₫ 359$ no. 6 StPO. In contrast, a strike out happens by a decision of the ECtHR which cites the original application (cf. rule 43 of the Rules of Court). In the case of pilot-judgment procedures, the strike out decision

159 See also Bajohr (fn. 133), pp. 94; Schmidt (fn. 76), $\$ 359$ margin no 40; F. Selbmann, Anpassungsbedarf der Regelungen zum Wiederaufnahmeverfahren an die Vorgaben der EMRK, Zeitschrift für Rechtspolitik (ZRP) 2006, p. 124 (125); Singelnstein (fn. 77 ), \$359, margin no 35. Different LG Ravensburg, NStZ-RR 2001, 115 (116).

160 See I. 1., II. 1.

161 Swoboda, HRRS 2009, p. 188 et seq. (192).

162 See, in detail, Brener, EuGRZ 2012, p. 1 et seq. (8 et seq.).

EuCLR Vol. 6, 1/2016 
refers to the pilot judgement that has found a violation of the ECHR. ${ }^{163}$ It would thus be possible to refer to the strike out decision in the context of $\$ 359$ no. 6 StPO. However, there is a practical problem: the Court generally decides to strike out applications in the aftermath of a pilot-judgement procedure if it is satisfied that the systematic problem has been remedied. If a reopening of the criminal trial was necessary on a large scale, the Court would probably not take kindly to the argument that a reopening would only be possible after the application had been struck out or otherwise decided because this would somehow defeat the purpose of the pilot-judgement procedure. Therefore, in these cases, there is indeed a need for an extensive interpretation of $\$ 359$ no. 6 StPO based on the European Convention on Human Rights.

This extensive interpretation is facilitated by the fact that the applicants in pilotjudgement procedures, whose applications are adjourned, have applied to the ECtHR and thus tried to achieve a decision by the Court that directly applies to them. If the German legislator reserves the extraordinary reopening procedure for those who actively sought a judgement by the ECtHR, this must also apply to similar cases that are not explicitly decided in the pilot-judgement procedure, but nevertheless affected. ${ }^{164}$ Accordingly, $\$ 359$ no. 6 StPO must be interpreted to apply to judgements that are adjourned due to the application of the pilot-judgement procedure. ${ }^{165}$

\section{c) Judgement by the ECJ}

German law does not allow the reopening of criminal proceedings after a judgement of the ECJ. There is no provision that refers to judgements by the ECJ. Nor was there any intention to include ECJ decisions in the reasons for reopening criminal proceedings. ${ }^{166}$ However, the question is whether the German law on reopening criminal proceedings, if interpreted in this way, complies with EU law.

As has been explained above, the rules on reopening procedures must comply with the principles of equivalence and effectiveness. This means that the recognition of EU law must be equivalent to national and international law. Therefore, similar to the questions raised by AG Jääskinen in Târşia, it is necessary to ask whether the reasons for reopening that are provided in German law for ECtHR decisions and decisions by the Constitutional Court ought to apply to EU law, too. ${ }^{167}$ If so, it will be considered which venues German law offers in order to achieve this aim.

163 See, e.g., European Court of Human Rights (Fourth Section) [ECtHR (4th s.)], E.G. v. Poland and 175 other applications, Application no. 50425/99, Decision 23 September 2008. The 175 other applications are cited in an annex.

164 See, on this issue, also Swoboda, HRRS 2009, p. 188 et seq. (192); Schmidt (fn. 76 ), $\mathbb{} 359$ margin no 40.

165 As the wording of $₫ 359$ no. $6 \mathrm{StPO}$ is ambiguous, it is not necessary to apply the provision analogously.

166 A change of law had originally been advocated, but did not become part of the proposal. Cf. BT Drs. 13/3594 and BT Drs. 13/10333.

167 Similarly H. Satzger, Die Europäisierung des Strafrechts, 2001, pp. 678. 


\section{a) $\$ 359$ no. $6 \mathrm{StPO}$}

According to $\ 359$ no. 6 StPO, the reopening of criminal proceedings is possible "if the European Court of Human Rights has held that there has been a violation of the European Convention on the Protection of Human Rights and Fundamental Freedoms or of its Protocols and the judgement was based on that violation." For this rule to also apply to EU law, the ECJ decisions and EU law would have to be similar to the situation described in $\$ 359$ no. 6 StPO.

There are several problems with doing so. First, it is far from clear whether a violation of the ECHR can really be compared to a violation of EU law. This is because the scope, aim and potential subjects of EU law are much larger than the scope of the ECHR. A violation of human rights can well be more serious than a violation of a technical provision of EU law. Furthermore, in contrast to a judgement by the ECtHR, a judgement by the ECJ can well be to the detriment of the defendant. For example, in Greek Maize the ECJ held that Greece had violated EU law by not prosecuting the perpetrators. ${ }^{168}$ Imagine that the perpetrators had been acquitted - in this situation, the reopening of proceedings to the detriment of the defendant might be in question. As $\$ 359$ StPO as a whole only covers the reopening for the benefit of the convicted person, this would probably also apply to EU law if this would fall within the scope of $\$ 359$ no. $6 \mathrm{StPO}$, but this issue shows that EU law and the ECHR are different in function.

However, the most obvious reason why ECJ decisions are not equivalent to ECtHR decisions for the purpose of $\$ 356$ no. 6 StPO is another: as has been explained, this provision only applies in cases where the defendant has himself applied to the ECtHR. ${ }^{169}$ Other judgements - apart from pilot judgements - cannot provide the reason for a reopening procedure. However, in EU law there is no individual application procedure that matches the one before the ECtHR. Most decisions concerning criminal law are rendered in a preliminary ruling, before a final judgement. It is thus hard to imagine a case where the individual who has been convicted later gains a judgement by the ECJ that states that his or her conviction violates EU law. For this reason, $\mathbb{\$} 359$ no. $6 \mathrm{ECtHR}$, even if applied to EU law, would not cover the situations that are problematic in EU law.

\section{bb) $\$ 79$ BVerfGG}

According to $\$ 79$ para. 1 BVerfGG, “new proceedings may be instituted [...] against a final conviction based on a rule which has been declared incompatible with the Basic Law or null and void in accordance with Article 78 above or on the interpretation of a rule which the Federal Constitutional Court has declared incompatible with the Basic

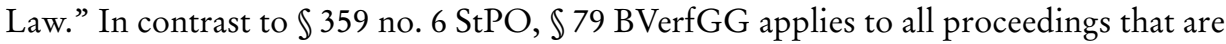

168 European Court of Justice (ECJ) 21.9.1989, case 68/88 (Commission v. Greece), [1989] ECR 2965 , margin no 22 et seq.

169 See also Satzger (fn. 167 ), p. 679.

EuCLR Vol. 6, 1/2016 
based on the law that was the basis of the decision by the Federal Constitutional Court. Thus, $\$ 79$ para. 1 BVerfGG could cover the situations arising out of ECJ decisions if it was applicable to EU law. Again, this is a question of equivalence and effectiveness.

Looking at the different ways in which the Constitutional Court can decide, it becomes clear that these are more similar to the decisions of the ECJ than those of the ECtHR. As the Constitutional Court does, the ECJ can decide on the incompatibility of national law with EU law or of a certain interpretation of national law. Although the ECJ does not have the power to declare national law void, its decision renders national law inapplicable. ${ }^{170}$ One might say that the voidness of a law is a stronger consequence than mere inapplicability. However, the Constitutional Court is not forced to assert the voidness of a law, but can also merely decide that a certain interpretation of criminal law is incompatible with Constitutional Law. In this case, national law is also inapplicable. ${ }^{171}$ The effect of judgements by the ECJ and the Constitutional Court is thus in both cases that the foundation for the criminal judgement is gone, either because it is void or because it cannot be applied. ${ }^{172}$ This is because both types of law national constitutional law and EU law - have a higher rank than national law in general. In fact, EU law even tops national constitutional law. In this regard, it would indeed be odd if the violation of constitutional law led to a reopening of criminal proceedings, but not the violation of (higher ranking) EU law. ${ }^{173}$ Therefore, EU law must be considered as equivalent to constitutional law in the context of $\$ 79$ BVerfGG. ${ }^{174}$ Accordingly, Art. 4 para. 3 TEU as the basis of the principles of effectiveness and equivalence demands the similar treatment of EU law and constitutional law for the purpose of reopening criminal procedures.

The question is how this demand can be met in German law. ${ }^{175}$ As has been said, $\$ 79$ BVerfGG, in referring specifically to the Federal Constitutional Court, does not leave room for much interpretation of its meaning. However, it is well established in the context of EU law that the Member States have to interpret national law as far as possible in conformity with EU law. This includes applying all methods for legal analysis that are used in the respective Member State. ${ }^{176}$ In German Law, another commonly used method of legal analysis is the analogue application of legal provisions. It is thus necessary to consider whether an analogue application of $\$ 79$ BVerfGG to ECJ decisions and EU law is feasible.

170 J. Jokisch, Gemeinschaftsrecht und Strafverfahren, 2000, p. 226.

171 Satzger (fn. 167), p. 680 et seq.

172 See also Satzger (fn. 167 ), p. 680.

173 See also Opinion of AG Jääskinen, Târşia (fn. 55 ), margin no 53.

174 Jokisch (fn. 170 ), p. 226. Doubting Bajobr (fn. 133 ), pp. 116.

175 See, in detail, Bajobr (fn. 133), pp. 105.

176 See O. Mörsdorf, Unmittelbare Anwendung von EG-Richtlinien zwischen Privaten in der Rechtsprechung des EuGH, Europarecht (EuR) 2009, p. 219 et seq. (222 et seq.). 
The requirements for an analogue application are, in brief, a gap in national legislation that is contrary to the legislative plan. ${ }^{177}$ There is clearly a gap in German legislation because there is no rule taking into account decisions by the ECJ. It is less clear whether this lack of legislation is contrary to the legislative plan or part of it. ${ }^{178}$ As a change of $\int 359$ StPO in order to include ECJ judgements had been suggested, the lack of legislation might be on purpose. This is the view taken by German jurisprudence. ${ }^{179}$ On the other hand, the Member States are obliged to follow EU law and thus, as has been pointed out earlier, Germany must provide an equivalent protection of EU law and ECJ decisions. There is no evidence that the legislator, when last changing $\mathbb{\$} 359$ StPO in 1998, was aware of this obligation. ${ }^{180}$ Under these circumstances, it can be assumed that the legislator's plan is to comply with EU law. It is thus feasible to apply $\$ 79$ BVerfGG to ECJ decisions. ${ }^{181}$

However, an analogous application of $\$ 79$ BVerfGG to ECJ decision requires decisions that are similar to Constitutional Court decisions, i.e. decisions that lead to the inapplicability of national law. This requirement is easily fulfilled if the ECJ has found a violation of EU law in an infringement procedure (Art. 258 TFEU), e.g. by claiming that certain criminal law provisions are contrary to EU law. Things are more difficult in case of the most common procedure before the ECJ, the preliminary ruling (Art. 267 TFEU). As a preliminary ruling is directed at the interpretation of EU law, the operative provisions of judgements in preliminary rulings do not usually declare the inapplicability of national law, but rather, that EU law has to be interpreted in a certain manner. Nonetheless, preliminary rulings will often inevitably lead to the inapplicability of national law. If that is the case in criminal proceedings, $\$ 79$ BVerfGG in its analogous application allows a reopening. Remaining doubts on whether national law is truly inapplicable must be addressed by the judge who presides over the reopening procedure.

These problems show that the analogous application of $\$ 79$ BVerfGG cannot be more than a temporary solution. In order to secure the effectiveness of EU law, the rule on going back on judgements in case of incompatibility with EU law should be unambiguous and clear. As $\$ 79 \mathrm{BVerfGG}$ does not explicitly provide for the reopening of criminal proceedings in these cases, it does not fulfil this criterion. Moreover,

177 This is generally accepted. See, e.g., H. Sauer, in: J. Krüper (ed.), Grundlagen des Rechts, $2^{\text {nd }}$ edition, 2013, $\mathbb{\$} 9$, margin no 40 .

178 Bajohr (fn. 133 ), p. 115.

179 OLG Karlsrube, Judgement 9 March 2006, 12 U 286/05, letter b) aa) (cited from juris); OLG Karlsrube, Judgement 9 August 2004, 3 Ws 182/04, margin no 5 (cited from juris).

180 See also OLG Karlsrube, Judgement 9 August 2004, 3 Ws 182/04, margin no 5 (cited from juris), where the Court stated that there was no need to apply $\$ 79$ BVerfGG analogously to ECJ decisions because EU law did not oblige the Member States to go back on res judicata.

181 See also Jokisch (fn. 170 ), p. 226 et seq.; Satzger (fn. 167 ), p. 680 et seq. Different OLG Karlsrube, Judgement 9 March 2006, 12 U 286/05 (cited from juris); OLG Karlsrube, Judgement 9 August 2004, 3 Ws 182/04, margin no 5 (cited from juris); Bajohr, who considers the analogue application to be contra legem, Bajobr (fn. 133 ), pp. 114; Singelnstein (fn. 77 ), $\$ 359$ margin, no 35.

EuCLR Vol. 6, 1/2016 
details such as which type of decisions of the ECJ gives rise to the reopening of proceedings are still unclear. ${ }^{182}$ Therefore, the German legislator needs to explicitly provide for a provision in the lines of $\$ 79 \mathrm{BVerfGG}$.

The analogue application of $\$ 79$ para. 1 BVerfGG cannot go further than the direct application of this article. This means that the restrictions identified above also apply to ECJ decisions. Therefore, if one follows the still prevailing interpretation under German law that restricts $₫ 79$ para. 1 BVerfGG to substantive criminal law, ECJ decisions are only important if they affect the substantive criminal law on which the decision is based, not if they affect procedural aspects. This is a considerable restriction, as a lot of recent EU legislation deals with legal assistance or other procedural matters. However, it is logical considering that the reason for applying $\$ 79$ para. 1 BVerfGG to EU law is not the need for a reopening procedure in general, but the need to treat EU law and German Constitutional Law equally. If one rejects this interpretation, the scope of $\$ 79$ para. 1 BVerfGG is much wider.

\section{d) Conclusion}

The analysis has shown that the German legislation leaves much to be desired. The common interpretation of $₫ 359$ no. $6 \mathrm{StPO}$ is too narrow in excluding pilot judgements from its scope. By not taking ECJ decisions into account when allowing a reopening in case of decisions by the Federal Constitutional Court, German law infringes the principles of equivalence and effectiveness, thus violating the principle of sincere cooperation (Art. 4 para. $3 \mathrm{TEU}$ ). Although the analogue application of $\$ 79$ BVerfGG is a possible solution, it cannot be more than temporary because it is far from providing clear and unambiguous access to the reopening procedure. A change in law is thus necessary. ${ }^{183}$

182 See Satzger (fn. 167 ), pp. 682.

183 To be continued in EuCLR 2/2016. 